\title{
Medierne tager stilling: De amerikanske mediers rolle under USA's krige i det tyvende århundrede
}

\author{
Af Carl Pedersen
}

Aviskongen William Randolph Hearst støttede varmt den spansk-amerikanske krig i 1898, der af USA's ambassador Fohn Hay blev kaldt "en vidunderlig lille krig." Til gengald vendte medierne sig imod krigen $i$ Vietnam, som tv-journalisten Walter Cronkite på åben skarm kritiserede med ordene: "Det synes mere sikkert end nogensinde, at den blodige Vietnamkonflikt ender $i$ skakmat." "Har jeg mistet Cronkite, har jeg mistet gennemsnitsamerikaneren," konkluderede Fohnson derefter. Og det havde presidenten ret $i$. Artiklen diskuterer mediernes stillingtagen til og dakning af de krige, USA har fort $i$ det tyvende århundrede fra Hearsts opfordring til krigsdeltagelse til brugen af 'embedded' journalister under krigen i Irak. Artiklen viser, at amerikanske medier ikke er upartiske i formidlingen af informationer, men opfatter sig selv som aktive medspillere $i$ krigens udvikling på hjemmefronten.

I 1899 hilste Senator Albert Beveridge det kommende århundrede med disse ord: "Det 20. århundrede bliver amerikansk. Den amerikanske tankegang kommer til at dominere det. Amerikansk fremskridt kommer til at præge og styre det. Amerikanske handlinger vil gøre det strålende" (Dos Passos, 1930, s. 5). Ved århundredeskiftet var USA i krig med Spanien. Mediernes rolle i den spansk-amerikanske krig var en forløber for det 20. århundredes krigsreportage. Den tegnede et mønster, der skulle, på trods af de teknologiske udviklinger inden for medieverdenen, vise sig at være karakteristisk for forholdet mellem medierne og staten under USA's krige i det 20. såvel som i det 21. århundrede. Den rejste spørgsmålet om mediernes uafhængighed af statens forsøg på at bruge pressen til at påvirke den offentlige mening. Den klarlagde mediernes rolle som enten ærkepatriotisk propagandistisk med en ukritisk holdning til amerikansk krigsførelse eller som iagttageren, der ofte imødegår den officielle version af krigshandlinger og krigsmål.

\section{"En vidunderlig lille krig"}

Det amerikanske århundrede begyndte med en krig i Caribien i 1898. Cuba havde mellem 1868 og 1878 været vidne til adskillige oprør mod det spanske imperiums undertrykkelse på sukkerplantagerne. I 1895 blussede urolighederne op på ny. Spanien forsøgte at knuse oprørerne ved bl.a. at internere rebelske landmænd i fangelejre. Samme år havde avisudgiveren William Randolph Hearst købt avisen The New York fournal. Hearst ejede allerede avisen The San Francisco Examiner, og han havde brugt aggressive metoder til at gøre avisen til den førende i byen. Han ønskede at gøre det samme i New York mod hovedkonkurrenten Joseph Pulitzers avis New York World og benyttede krisen på Cuba til at opnå sit mål. I adskillige ledere og overskrifter forsøgte Hearst og Pulitzer at oppiske folkestemningen til støtte for oprørsstyrkerne på Cuba.

Budskabet fra disse sensationsaviser blev hjulpet godt på vej af en identitetskrise, der plagede amerikanerne i 1890'erne. En depression i 1893 havde vakt usikkerheden om den amerikanske økonomiske model og havde tillige fremprovokeret et antimodernistisk landligt oprør mod den hurtige industrialisering af nationen. Den stigende indvandring fra Syd- og Østeuropa af befolkningsgrupper med en anden etnisk og religiøs baggrund end den dominerende angelsaksiske gruppe havde fremkaldt bekymringer over amerikanske kerneværdier. Kvindebevægelsen havde sat spørgsmålstegn ved kvindernes traditionelle roller 
i samfundet. Industrialiseringen havde også medført en opblomstring af en "business" kultur, hvis selvoptagethed og pengegriskhed var et slag mod samfundssind og selvopofrelse (Ninkovich, 2001).

Den kulturelle rådvildhed, der prægede samfundet i 1890'erne, var medvirkende til, at den amerikanske offentlighed ikke blot forfærdedes over begivenhederne på Cuba, men ligefrem ønskede, at USA skulle handle i oprørernes forsvar. USA's rolle kunne ses fra både et negativt og et positivt perspektiv. USA kunne tage parti for den svage side mod den europæiske imperialismes undertrykkelse og atter vise, at USA var et exceptionelt land, der baserede sin identitet på at være en modgift mod Europa. Ved at intervenere i Cuba kunne USA tillige udføre samme civiliserende mission, der også havde kendetegnet den kontinentale ekspansion vestpå i det 19. århundrede.

Hearst ønskede, at USA skulle føre krig mod Spanien, og i 1896 eskalerede han sin kampagne for at få den amerikanske regering til at handle. Han sendte journalisten Richard Harding Davis og kunstneren Frederick Remington til Cuba, og pligtopfyldende indsendte de gruopvækkende beretninger om de spanske overgreb på oprørsstyrkerne. På et tidspunkt hvor Remington meddelte Hearst, at der var relativt stille og ikke så meget at berette, og at han derfor ønskede at vende hjem, skulle Hearst have svaret per telegram: "Vær venlig at blive. Forsyn mig med billeder og jeg skal nok stå for krigen." Selvom historien om telegrammet senere har vist sig at være opdigtet, udtrykker den ikke desto mindre, hvad Hearst anså for at være sin opgave som redaktør - at få den offentlige opinion til at lægge pres på regeringen til at støtte de cubanske oprørere militært (Campbell, 1995, s. 10). Sensationspressen holdte sig ikke tilbage fra at fremstille spanierne som barbarer, der brutalt undertrykte de frihedselskende oprørere. Hearst skulle snart få hjælp til sin sag fra uventet hold.

I februar 1898 sejlede det amerikanske krigsskib USS Maine til havnen i Havana, Cuba, for at 'vise flaget' og udtrykke USA's bekymring over ustabiliteten på øen. D. 15. februar eksploderede krigsskibet, og 260 besætningsmedlemmer døde. Sensationspressen anklagede straks Spanien for tragedien. ${ }^{1}$ Hearst fik sin krig, og USA fik en sag, der kunne bidrage til løsningen af den nationale identitetskrise. USA fremstod som et land med en mission, der skulle frelse 'primitive' befolkningslag rundt om i verden.
Den spansk-amerikanske krig gav sensationspressen vind i sejlene. Den kunne øge oplaget ved at fortælle overdrevne og følelsesladede historier om oprørernes lidelser eller de amerikanske troppers heltemodige gerninger. Theodore Roosevelt slog sit navn fast $\mathrm{i}$ amerikanernes bevidsthed som leder af de såkaldte Rough Riders, der fik en stor sejr ved San Juan Hill i 1898. Før krigen var Roosevelt en af de varmeste fortalere for nødvendigheden af selvopofrelse og maskulinitet for at få USA ud af sin identitetskrise. Krigen havde givet ham og hans land en ny mission i Beveridges amerikanske århundrede. Beveridge kunne i begejstrede vendinger tale om det amerikanske flags fremmarch (Beveridge, 1898). Det var ikke uden grund, at USA's ambassadør i Storbritannien, John Hay, betegnede konflikten som "en vidunderlig lille krig."

Selvom en stor del af mediernes dækning af krigen var præget af Hearsts og Pulitzers forsøg på at overgå hinanden med store og ofte løgnagtige overskrifter, lavede andre hæderlig journalistik. New York-aviserne The New York Times, The Herald og The Tribune lod sig ikke friste af Hearsts og Pulitzers underlødige journalistik. Forfatteren Stephen Crane skrev således artikler, der var skarpsindige og analytiske. ${ }^{2}$ Selvom han fra tid til anden arbejdede for Hearst, formåede journalisten Richard Harding Davis også at modstå sensationalisme. Davis var i øvrigt repræsentant for en ny slags journalist. I modsætning til tidligere journalister som blev set ned på som løsslupne drukkenbolte, var Davis fra middelklassen og universitetsuddannet. Davis' reportage om de amerikanske troppers sejr ved San Juan Hill i 1898 var med til at gøre Roosevelt landskendt, hvilket gavnede ham i hans politiske virke (Traxel, 1998).

\section{Krigen for at gøre verden sikker for demokratiet}

USA har gennem sin historie betragtet sig selv som et antiimperialistisk land. Siden landets oprindelse efter Uafhængighedskrigen (1775-1783) havde en afstandtagen fra Europas imperialistiske krige været del af den amerikanske selvforståelse. Den spansk-amerikanske krig og den efterfølgende annektering af Filippinerne, Hawaii og en række andre småøer i Stillehavet $\mathrm{i}$ begyndelsen af det amerikanske århundrede er således blevet betegnet som en afvigelse fra USA's traditionelle rolle i verden som en antikolonimagt, der udgjorde en modvægt til den europæiske imperialisme. 
Set i historiens bakspejl var hvad man kan kalde "det imperialistiske øjeblik", hvor USA udøvede direkte kontrol over udenlandske territorier, ikke så meget en afvigelse som en forstærkning af ekspansionslysten, der dog i det 20. århundrede mere manifesterede sig som et uformelt imperium med indirekte kontrol over f.eks. et lands økonomi.

Den spansk-amerikanske krig var populær i den amerikanske befolkning, netop fordi den (omend ubevist) banede en vej ud af 1890'ernes identitetskrise. Den trykte presse havde sin andel i at føre landet tilbage til en fra statsmagtens side betragtet patriotisk målrettet kurs med billeder og beretninger af soldater fra både Nord- og Sydstaterne, som for første gang siden den amerikanske borgerkrig (1861-1865) kæmpede side om side.

Mens den spansk-amerikanske krig og den efterfølgende filippinske krig foregik i områder, som USA betragtede som sin interessesfære, virkede de europæiske slagmarker under Første Verdenskrig anderledes fjerne. Den gamle advarsel om ikke at blive involveret i europæernes konflikter, som USA's første Præsident George Washington kom med i sin afskedstale i 1796, syntes stadig relevant. I 1915, kort efter at krigen i Europa var brudt ud, havde D.W. Griffiths film om den amerikanske borgerkrig Birth of a Nation premiere i USA. Filmens epigraf, der udtrykte forfærdelse over krigens gru, var rettet ikke blot mod krigen i 1860'erne, men mod den nuværende krig i Europa. Da Woodrow Wilson skulle føre kampagne til sit genvalg i 1916, var ét af hans slogans: "Han holdt os ude af krigen." Ikke desto mindre gik USA ind i Første Verdenskrig mindre end et halvt år efter Wilsons genvalg, i april 1917.

USA gik ikke kun ind i Første Verdenskrig på grund af Tysklands direkte militære provokationer - såsom tyske ubådes angreb på amerikanske fartøjer og Tysklands kluntede forsøg på at få Mexico til at føre krig mod USA - men fordi amerikanske finans- og erhvervsinteresser så et stærkt Tyskland som en trussel mod en amerikansk domineret verdensorden. Derfor var præsident Woodrow Wilsons 14 Punkter -bl.a. frihandel, selvbestemmelsesret og en ende på kolonialismen - et forsøg på at gøre den ellers regionale 'åben dørs'-politik mere global ved at åbne flere markeder til amerikansk overproduktion. Krigen, der ifølge den officielle amerikanske politiske retorik skulle "gøre verden sikker for demokratiet," skulle for USA sikre en ny verdensorden styret af amerikanske økonomiske interesser. Den amerikanske regerings promovering af demokrati strakte sig imidlertid ikke til afroamerikanerne i USA. Amerikanske politikere var imod oprettelsen af det internationale fredsskabende organ Folkeforbundet, fordi de frygtede, at den internationale organisation ville stække USA's politiske, økonomiske og militære råderum $\mathrm{i}$ verden.

På trods af Wilsons opfordring til at kæmpe for demokrati og selvbestemmelse i Europa var USA's deltagelse i krigen upopulær i store dele af befolkningen. Dette forhold blev afspejlet i medierne. I modsætning til hvad man nærmest kan kalde en form for krigsliderlighed op til den spansk-amerikanske krig, fastholdt Hearst, at USA skulle forblive neutralt, i hvad han betegnede som "kongernes krig." Hearst mente, at USA skulle opnå størst mulige fordele ved at holde sig uden for konflikten i Europa. Han var dog bekymret for, at en svækkelse af den europæiske civilisation som resultat af krigens ødelæggelser kunne betyde, at uciviliserede asiater kunne opnå global dominans (Mugridge, 1995, s. 34-5). Hearsts aviser tog derfor hverken parti for den ene eller den anden part i krigen. Kort efter den amerikanske krigserklæring oprettede Wilson The Committee on Public Information under ledelse af journalisten George Creel. Udvalget, som rekrutterede medlemmer fra erhvervslivet, medieverdenen og universiteterne, fik som opgave at fremme støtten for krigen på hjemmebanen og at oplyse om den amerikanske krigsmission i udlandet. Det fungerede som en slags reklamebureau for regeringens politik ved at gøre brug af den nye teknologi, filmen, til at sprede sit budskab. Wilson-regeringen forsøgte også at dæmme op for kritikere af krigen ved i 1917 og 1918 at få vedtaget love, der bl.a. begrænsede den forfatningssikrede pressefrihed.

En af de mest kritiske røster mod USA's deltagelse i krigen var det venstreorienterede tidsskrift The Masses. Journalisten og venstrefløjsaktivisten John Reed, som senere skrev øjenvidneberetningen Ti dage der rystede verden (1918) om den bolsjevitiske revolution, anså krigen for at være en kamp mellem imperialistiske magter, hvor den menige soldat kun fungerede som kanonføde. ${ }^{3}$ Som reaktion mod bl.a. regeringens undertrykkelse af pressefrihed under Første Verdenskrig blev The American Civil Liberties Union dannet i 1920. I modsætning til Reed var Richard Harding Davis' reportage fra krigen med til at promovere konflikten som et amerikansk korstog for demokrati. Den 
afroamerikanske leder W.E.B. Du Bois støttede krigen, fordi han mente, at kampen for demokrati i Europa kunne betyde en ende på diskrimination og racisme i USA. Hans ønske blev dog ikke indfriet, og det var først efter Anden Verdenskrig, at kampen for fulde borgerrettigheder for afroamerikanere tog til (Lewis, 1993, s. 555-7).

Det var ikke kun i den trykte presse, at krigen fik indvirkning på den offentlige mening. Sangen "How Ya Gonna Keep 'Em Down on the Farm" (1918) udtrykte en helt anden angst over den amerikanske krigsdeltagelse - at unge mænd fra landet skulle blive så betaget af det pulserende liv i storbyen Paris, at de ville vægre sig ved at vende tilbage til livet på landet. Underholdningsindustrien var dermed med til at forme amerikanske meninger ikke blot om krigsdeltagelsen, men om den påståede dekadente europæiske kultur.

Filmbranchen var på barndomsstadiet under Første Verdenskrig. Ikke desto mindre kom der to film under krigen, der gav et fingerpeg om, hvordan filmindustrien så USA's rolle i krigen. The Star Spangled Banner (1917) fik premiere før USA gik ind i krigen i april 1917, men dens fortælling om en træningsbase for marinesoldater under Første Verdenskrig var tydeligvis tænkt som en opfordring til det amerikanske folk om at støtte de allierede. The Unbeliever (1918) havde premiere, efter USA havde erklæret de Centrale magter med Tyskland i spidsen krig. Filmen, der blev lavet med Marinekorpsets fulde støtte, havde et patriotisk budskab og viste tyske grusomheder. I Denver, Colorado, havde Marinekorpset opsat en indmeldingsbod i lobbyen af filmteatret, og hundredvis af mænd meldte sig ind efter at have set filmen. ${ }^{4}$

Pressen var med til både at så tvivl om USA's deltagelse i Første Verdenskrig og til at støtte Wilsons geopolitiske vision. Den del af den amerikanske selvforståelse, der så indblanding i europæiske anliggender som en fare for et land, der definerede sig imod Europa, kom klart til udtryk i befolkningens modstand mod amerikansk deltagelse i Folkeforbundet. Isolationister i Kongressen betragtede den nye internationale organisation som en fare for amerikansk handelsfrihed. Senator Beveridge mente, at Folkeforbundet var en samling "gamle bedsteforældre", der ønskede at "afnationalisere Amerika og afnationalisere nationens manddom" (Nash et al, 1994, s. 775). Forholdet mellem stat og medier var tvetydigt - på den ene side forsøgte Wilson-regeringen at dæmme op for kritiske røster i medieverdenen med lovgivning, der begrænsede ytringsfriheden. På den anden side samarbejdede Krigsministeriet og underholdningsindustrien frivilligt om film, der havde patriotiske budskaber.

\section{Den gode krig}

Kongressens afvisning af amerikansk medlemskab af Folkeforbundet understregede mange amerikaneres ønske om at trække sig tilbage fra omverdenen. I 1940 stod USA imidlertid over for en verden, hvor aggressive magter gennem erobring havde truet det amerikanske kapitalistiske system ved at lukke markeder i Vesteuropa og Indokina. Som præsident Franklin D. Roosevelt udtrykte det, var "handelsfrihed ... afgørende for vor økonomiske overlevelse." USA's overordnede mål i Anden Verdenskrig var ikke så meget at knuse nazi-Tyskland, som det var at hindre én statsmagt i at dominere Europa og dermed begrænse USA's frie adgang til kontinentets markeder. USA udkæmpede, hvad der senere blev betegnet som "den gode krig", for at kunne skabe det geopolitiske grundlag for en verdensorden efter krigen, som skulle domineres af USA's økonomiske interesser på længere sigt.

USA's neutralitet blev brat afbrudt af det japanske overraskelsesangreb på flådebasen Pearl Harbor på den amerikanske koloniø Hawaii d. 7. december 1941. I de næste 50 år, under Anden Verdenskrig og senere den Kolde Krig, skulle USA forblive engageret $\mathrm{i}$ verden gennem sin stigende magt og indflydelse.

Radioen kom til at spille en stor rolle for mediedækningen under Anden Verdenskrig. Franklin D. Roosevelt var den første præsident, der effektivt brugte radioen i politisk øjemed med sine "Fireside Chats" (samtaler ved pejsen) i 30'erne og under krigen. Roosevelt fortalte befolkningen om sine planer for nationen og opfordrede amerikanerne i disse samtaler til at fortælle ham om deres problemer. Radioudsendelsernes afslappede form gjorde det muligt for Roosevelt at etablere et tæt bånd mellem staten og folket. Eftersom $90 \%$ af amerikanerne ejede en radio ved slutningen af krigen og lyttede i gennemsnit fire timer om dagen, nåede Roosevelt ud til mange hjem med sit budskab om USA's kamp for frihed i Europa.

Journalisterne brugte også radioen flittigt til at rapportere hjem om situationen i Europa. Edward R. Murrows, der ofte begyndte sine radioudsendelser med ordene "dette er London ...", rappor- 
terede om tyskernes bombninger af britiske byer. William Shirer fortalte amerikanerne om Hitlers Tyskland fra Berlin. Ernie Pyles indsigtsfulde journalistik om soldaternes dagligdag gjorde ham til den mest læste krigskorrespondent, endda før hans død på Okinawa i $1945 .{ }^{5}$

De fleste journalister undergav sig uden protest den pressecensur, som The Office of Censorship, oprettet kort efter Pearl Harbor, stod for. Krigen mod nazisterne og japanerne nød bred opbakning blandt befolkningen og i medierne. Journalisterne opfattede sig selv for det meste som en del af kampen for den gode sag.

Anden Verdenskrig fremstår i den amerikanske kollektive bevidsthed som 'den gode krig', hvor USA gjorde en ende på fascisme i Europa og på Japans imperium i Asien. Medierne var med til at skabe dette erindringsfællesskab. Instruktøren Frank Capra, som var major i den amerikanske hær, lavede en række film under krigen med fællestitlen Why We Fight (1943-45), hvis formål var at forklare USA's politik til rekrutter. Umiddelbart efter krigen lavede Hollywood en del film, der bidrog til myten om den gode krig. Et eksempel er The Sands of Iwo Fima (1949) med John Wayne. Hovedrollen som Sergeant Stryker, der leder sine mænd i kamp for at erobre øen Iwo Jima, inspirerede unge mænd. Således kunne Ron Kovic, der blev lammet under Vietnamkrigen, berette i sin biografi Born on the Fourth of Fuly (1976), hvordan filmen fik ham til at melde sig som soldat (Suid, 2002, s. 130). Journalister såvel som filmskabere leverede beretninger om amerikanske soldaters heltegerninger, der stadig giver genlyd i det 21. århundrede.

Historikeren Paul Fussell spørger imidlertid, om ikke Anden Verdenskrig blev udkæmpet i et ideologisk vakuum, der handlede om hævn for Pearl Harbor. Fussell mener, at konstruktionen af myten om den gode krig kom som en eftertanke og har haft et langt liv i amerikanernes erindringsfællesskab (Fussell, 1990, s. 138-41).

\section{En nødvendig krig}

Var Anden Verdenskrig amerikanernes 'gode krig', blev Vietnam til gengæld deres mareridt. Amerikanernes selvtilstrækkelighed led et knæk under denne krig, der strakte sig fra 1961, hvor Præsident Kennedy sendte de første militære rådgivere til Sydvietnam, til 1975, hvor USA led det første militære nederlag i landets historie.
Vietnamkrigen er et vendepunkt i amerikanske mediers dækning af krig. En del af de journalister, der dækkede Vietnamkrigen, havde været krigskorrespondenter under Anden Verdenskrig. I Vietnam stod de over for en ny slags krig, som ikke blev udkæmpet på de store slagmarker, men i stedet mod en usynlig fjende, der gemte sig i junglen og førte guerillakrig mod de amerikanske styrker. Desuden blev Vietnamkrigen kaldt for "TV-krigen", fordi amerikanerne for første gang kunne opleve konflikten hver aften i deres dagligstuer. I begyndelsen af krigen fik amerikanerne fortrinsvis deres nyheder om krigen fra den trykte presse, som videregav oplysninger til tv-stationer. TV-stationerne havde også krigskorrespondenter i Vietnam, og de skrev lige som avisjournalister deres historier, der kom i fjernsynet med et par dages forsinkelse. Samtidig med at Johnson-regeringen sendte flere tropper til Vietnam efter 1965, skete en teknologisk udvikling, der gjorde det muligt for journalister og fotografer at sende deres beretninger næsten direkte til det amerikanske folk. Aften efter aften viste de store netværker optagelser af grusomme kampe, der chokerede amerikanerne.

Det definitive vendepunkt kom under Tet-offensiven i begyndelsen af 1968. Nordvietnamesiske og Vietcong-styrker indledte et massivt angreb på flere mål i Sydvietnam og trængte ind på den amerikanske ambassade i Saigon. Rent militært var offensiven et nederlag for kommunisterne, men kan betegnes som en vigtig psykologisk sejr. Tvjournalisten Walter Cronkite blev på det tidspunkt betragtet som indbegrebet af journalistisk hæderlighed og sandfærdighed. Mod sædvane sluttede Cronkite sin nyhedsudsendelse d. 27. februar 1968 med sin egen mening om, hvad Tet betød for amerikansk krigsførelse i Vietnam: "Vi er alt for ofte blevet skuffet af de amerikanske lederes optimisme, både i Vietnam og i Washington, til længere at kunne tro, at solen altid skinner bag skyerne ... for det synes mere sikkert end nogensinde, at den blodige Vietnamkonflikt ender i skakmat" (Croncrite, 1998, s. 581). Efter at have hørt Cronkites udsendelse, sagde Præsident Johnson til en rådgiver, "Det var det. Har jeg mistet Cronkite, har jeg mistet gennemsnitsamerikaneren" (Anderson, 2001). Et image, der fæstnede sig i amerikanernes bevidsthed under Tet-offensiven var fotografen Eddie Adams' optagelse af en sydvietnamesisk officer, der roligt sætter en pistol mod tindingen af en Vietcong-fange og skyder ham på åben gade. 
Pressen nød friheden til at rejse rundt i Vietnam og sende beretninger hjem uden Pentagons indblanding. Det blev en udbredt opfattelse hos mange militære ledere, at det netop var medierne, der undergravede den amerikanske mission i Vietnam ved at så tvivl hos den amerikanske offentlighed om retfærdigheden af krigen. Derfor var militæret opsat på ikke at give medierne så frie tøjler i fremtidige krige.

Vietnamkrigen kan betragtes som en nødvendig krig, hvad angår forholdet mellem medierne og staten, fordi den gjorde op med den symbiose mellem journalister og magthavere, der havde kendetegnet mediernes rolle siden den spansk-amerikanske krig. Journalisternes reportage fra slagmarken var med til at afsløre misforholdet mellem den amerikanske regerings udlægning af krigen og det faktum, at USA var langt fra at have vundet krigen i slutningen af 60'erne. Medierne bidrog til en stigende modstand i den amerikanske offentlighed mod USA's krigsførelse i Sydøstasien, noget som de politiske og militære ledere frygtede. Som journalisten Chris Hedges udtrykte det, "Vi blev ydmyget i Vietnam, renset, for en tid, for en farlig hybris ... Vi blev et bedre land" (Hedges, 2003, s. 17). ${ }^{6}$

\section{Mod den virtuelle krig}

I 80'erne blandede USA sig i to konflikter i Mellemamerika og Caribien, områder som amerikanerne betragtede som deres interessesfære siden Monroe-doktrinen i 1823, som forbød yderligere europæisk indblanding i den vestlige halvkugle. USA's invasioner på øen Grenada i 1983 og i Panama i 1989 er af den konservative kommentator Max Boot blevet betegnet som "små krige", der ligesom den spansk-amerikanske krig gav USA hurtige og relativt set ublodige sejre. Med Vietnamkrigen i frisk erindring besluttede det amerikanske militær at holde medierne på afstand af disse konflikter (Boot, 2002; Anderson, 2001).

Golfkrigen i 1991 var noget andet. Den var en storstilet operation med luftangreb efterfulgt af en kortvarig landkrig. En af de vigtigste ændringer i dækningen af Golfkrigen var kabel-tv. CNN blev grundlagt i 1980 af Ted Turner. Netværket havde klaret sig relativt pænt, men fik især vind i sejlene under Challenger-ulykken i 1986, da det var på pletten, da tragedien skete. CNN-journalisterne Bernard Shaw og Peter Arnett var i Bagdad, da USA indledte et massivt luftangreb mod byen $\mathrm{d}$.
17. januar 1991. Men der var flere ulemper ved live dækning 24 timer i døgnet. I relativt stille perioder viste $\mathrm{CNN}$ de samme optagelser om og om igen. For journalisterne betød den øjeblikkelige dækning, at der manglede tid til refleksion eller dyberegående analyse af begivenhederne, i modsætning til journalistikken under Anden Verdenskrig.

Pentagon så propagandaværdien i den konstante nyhedsdækning. CNN og andre netværker troppede op til de daglige briefinger, som militæret afholdt, for at vise videooptagelser af effekten af de såkaldte "smart bombs." Dick Cheney, som var forsvarsminister under den ældre Bush, bemærkede, at briefingerne gjorde det muligt at styre informationsstrømmen. "Smart bombs" udgjorde således kun seks procent af de bomber, der blev anvendt under Golfkrigen. Pentagon valgte ikke at fremvise effekten af almindelige bomber, som ofte ramte ved siden af (Sloyan, 2002).

Præsident Bush mente, at Golfkrigen kunne føre USA ud af 'Vietnamsyndromet' og gøre det muligt for USA at foretage en mere aktiv udenrigspolitik. Han og hans rådgivere vidste, at pressen kunne spille en afgørende rolle for at få den nødvendige opbakning fra offentligheden til krigsførelse. Derfor forlangte Forsvarsministeriet, at journalisterne skulle samles i et "pool system", hvorved de kun kunne færdes i krigszonen med militære ledsagere. CNN-journalisten Christiane Amanpour fortalte, at hun blev placeret på et hangarskib i det Røde Hav langt væk fra slagmarken. ${ }^{7}$

På en måde fik Golfkrigen den modsatte effekt af Vietnamkrigen, netop som ønsket af Bush-regeringen. Befolkningens opbakning til krigen kom, fordi de billeder, folk så af ørkenkrigen, var så anderledes end dem, de huskede fra junglekrigen i Vietnam. Blot to år efter blussede Vietnamspøgelset op i det amerikanske erindringsfællesskab. USA havde i 1992 indsat tropper i Somalia for at hjælpe FN med at afværge en humanitær katastrofe forårsaget af somaliske krigsherrers interne magtkampe. Under et forsøg på at kidnappe en krigsherre i 1993 kom amerikanske soldater i krydsild, og 18 blev dræbt. GNN kunne samme aften vise billeder af liget af en amerikansk soldat, der blev slæbt gennem Mogadishus gader. Præsident Clinton valgte kort derefter at trække alle amerikanske tropper ud af landet. Frygten for de politiske konsekvenser af tab af amerikanske soldaters liv under internationale operationer var ikke blot noget, der optog de amerikanske ledere. Under Balkan-kon- 
flikten viste serbisk tv optagelser med den døde amerikanske soldat igen og igen. Den saudiarabiske terrorist Osama bin Laden nævnte også USA's tilbagetrækning fra Somalia i sin j̈had som et tegn på amerikanernes svaghed.

Med undtagelsen af den mislykkede aktion i Somalia bevægede USA's krigsførelse sig fra Golfkrigen i 1991 til amerikanernes luftbombardementer i Kosovo i 1999 hen imod hvad man kan kalde virtuel krig - uden landtropper og uden tab. Krig var i færd med at blive uvirkelig både for soldaterne og for den amerikanske befolkning. Konsekvensen blev, at det netop var i 90'erne, at underholdningsindustrien lavede en række film om den gode krig. Det virkede, som om filmskabere i Hollywood frygtede, at amerikanerne ville tabe enhver form for sammenhold i et postheroisk samfund, hvis ikke de blev mindet om deres glorværdige fortid. Saving Private Ryan, Pearl Harbor og tv-serien Band of Brothers forsynede amerikanerne med et patriotisk erindringsællesskab om USA's godhed og udholdenhed.

\section{Krigen for at lave om på verden}

Efter den kolde krigs afslutning så mange konservative republikanere en mulighed for, at det 21. århundrede også skulle blive et amerikansk århundrede. I 1992 udarbejdede to rådgivere for daværende forsvarsminister Cheney - Paul Wolfowitz og I. Lewis Libby (nu henholdsvis viceforsvarsminister og stabschef for vicepræsident Cheney) - en plan, som fremlagde en vision om amerikansk militær overlegenhed, der skulle sikre, at ingen rivaliserende supermagt skulle dominere Europa, Asien eller det forhenværende Sovjetunionen. USA's 'godgørende' dominans skulle erstatte princippet om kollektiv internationalisme.

En kombination af militær styrke, moralsk klarhed og et ønske om økonomisk overlegenhed lå bag tankerne om et amerikansk imperium. Et nyt amerikansk århundrede er ved at tegne sig. EU-udvidelsen har gavnet USA ved at optage proamerikanske central- og østeuropæiske nationer. NATO-udvidelsen efter amerikanske foreskrifter har styrket USA's politiske og militære kontrol i Europa. USA har nu militært fodfæste i de forhenværende sovjetiske centralasiatiske republikker. Den forestående krig med Irak vil sikre USA indflydelse på landets enorme oliereserver. Viceudenrigsministeren for afrikanske anliggender har udtalt, at afrikansk olie også "er blevet en national sikkerhedsinteresse" for USA.

Ifølge forfatteren Norman Mailer var USA i identitetskrise efter den kolde krig. For konservative republikanere var det chokket fra d. 11. september, der bragte amerikanerne ud af, hvad de konservative anså for at være deres rådvildhed. I bogen Why We Fight: Moral Clarity and the War on Terrorism påpegede William Bennett, forhenværende undervisningsminister under Reagan, nogle af de positive effekter terrorangrebet $d$. 11. september 2001 havde på den amerikanske befolkning: "Lige pludselig syntes alt småligt, selvoptaget, hadsk, dekadent og fjendtligt $\mathrm{i}$ vores nationale liv at blive fejet bort. Pludselig var landets flag overalt og forblev overalt. Lige pludselig havde vi helte igen." D. 11. september gav amerikanerne "moralsk klarhed" til at genopdage sig selv som et folk. Mailer anså derimod stemningen for at være en patriotisk feber, der gjorde USA mere arrogant og forfængeligt (Bennett, 2002, s. 11; Mailer, 2003, s. 10-15).

Hollywood meldte sig under fanerne. Jack Valenti, formand for The Motion Picture Association of America, mødtes med repræsentanter fra Bush-regeringen (blandt andet Karl Rove, Bushs indenrigspolitiske rådgiver) i november 2001 for at aftale, hvordan Hollywood kunne hjælpe i krigen mod terrorisme. Mødet blev bagefter betegnet som "begyndelsen til en begyndelse" uden nogle specifikke planer om samarbejde mellem underholdningsindustrien og regeringen, ud over at Hollywood ville sende film og filmstjerner til tropper udstationeret i udlandet. ${ }^{8}$

Hvis CNN dominerede Golfkrigen i 1991, vandt konservative Fox News - del af Rupert Murdochs Fox-netværk - seere under krigen mod terrorisme. Fox News lagde ikke skjul på sin partiske holdning til republikansk udenrigspolitik. Nyhedschefen Roger Ailes havde ledet den ældre Bushs genvalgskampagne i 1992 og havde tætte forbindelser til Bush-familien. Selvom Fox promoverede sig selv som en "fair and accurate" nyhedskanal var det tydeligt, at værter som Bill O'Reilly og Geraldo Rivera støttede regeringens udenrigspolitik. Fox News var blot én blandt mange konservative mediekanaler, der sluttede op omkring de konservative republikaneres visioner. Især "talk radio"værter som Rush Limbaugh og G. Gordon Liddy bidrog til en højredrejning af nyhedsdækningen. ${ }^{9}$

Krigen mod terrorisme blev af en ledende neokonservativ, Michael Ledeen, betegnet som intet 
mindre end "en krig, der skulle lave om på verden" (Dreyfuss, 2003). I modsætning til Golfkrigen hvor militæret gjorde, hvad det kunne for at holde pressen langt væk fra kamphandlinger, ændrede Pentagon taktik under Irakkrigen i 2003 og oprettede en ordning, hvorved udvalgte journalister - såkaldte "embedded journalists" - ledsagede amerikanske soldater i felten og rapporterede om såvel deres dagligdag som deres liv i krig. Ifølge journalisten Chris Hedges udgør denne taktik en fare for journalisternes uafhængighed: "Journalisterne har ikke adgang til egen transport. De er afhængige af militæret med hensyn til alt fra mad til et sted at sove. De regner med, at soldaterne vil beskytte dem. Når de føler frygt under fjendtlige skududvekslinger, identificerer de sig med og søger at beskytte de, som beskytter dem. Det er en naturlig reaktion. Jeg har følt den" (Hedges, 2003).

Internet og e-mail var stort set ikkeeksisterende under Golfkrigen. Brugen af e-mail er steget betydeligt inden for de seneste år og mange af de soldater, der kæmpede i Irakkrigen og fik deres turnus i landet forlænget p.g.a. den langsomme genopbygningsproces, sendte e-mails til pårørende i USA. De gav udtryk for vrede og frustration over, at Pentagon ikke havde fortalt, hvornår de kunne vende hjem. Bølgen af e-mails fra Irak gjorde soldaterne til amatørjournalister uden om de store netværker og aviser. De kunne løbende rette kommentarer, der gik imod den officielle version af krigen og genopbygningsprocessen (Harris \& Franklin, 2003). Kameraer i mobiltelefoner er endnu en teknologisk fornyelse, der gjorde det muligt for soldater at lave journalistiske produkter. Denne teknologi fik uventede følger, da billeder af amerikansk tortur mod irakiske fanger i Abu Ghraib fængslet så dagens lys i The New Yorker og nyhedsprogrammet 60 Minutes (Hersh, 2004). De gruopvækkende billeder skabte tvivl om den amerikanske mission, ikke blot i den arabiske verden, men også hos USA's allierede og blandt amerikanere.

Ligesom under den Kolde Krig opfordrede konservative kræfter til militarisering af samfundet. Præsident Bushs rådgivere iscenesatte mediebegivenheder for at sætte USA's øverstkommanderende i det bedste lys, gerne med militæret som kulisse. Bush fremstod gerne som landsfader; blandt andet på militærakademiet West Point, hvor han i 2002 lancerede sin doktrin om præventiv krig; eller da han d. 1. maj 2003 på et hangarskib med banneret "Mission udført" bag sig erklærede kamphandlingerne i Irak for overståede; og da han på Thanksgiving d. 27. november 2003 besøgte et par hundrede soldater i Bagdad. Disse photo-ops er en vigtig del af det Hvide Hus' forsøg på at opretholde befolkningens støtte til krigen mod terrorisme (Nichols, 2003).

Ved første øjekast opfyldte historien om Jessica Lynch også Bush-regeringens krav til retfærdig patriotisme: en ung kvindelig soldat fra beskedne kår blev befriet fra fangenskab. Men redningsaktionen viste sig at være iscenesat, og Lynch har i interviews udtrykt sin bekymring over at være blevet manipuleret af militæret. ${ }^{10}$ Pentagon forbød fotografering af kister med døde soldater fra Irakkrigen, men har ikke kunne standse de daglige nyheder om amerikanske tab i den guerillakrig, der har fortsat siden d. 1. maj 2003.

Ved begyndelsen til et nyt amerikansk århundrede er USA i færd med en langvarig krig for at lave om på verden. Den konservative republikanske regering har brug for befolkningens støtte til et så grandiost projekt. Den højredrejning, medierne har foretaget i 90'erne, har bidraget til befolkningens accept af Bush-regeringens globale visioner. De-reguleringen af medierne i 1996 har blandt andet betydet, at multinationale koncerner har overtaget styringen af mange aviser og tv-netværker. Rupert Murdoch-ejede netværk Fox støtter således åbenlyst Bush-regeringens politik. Ikke nok med det. En rapport fra University of Maryland viser, at de fleste amerikanere tror på mindst en af tre 'fejlopfattelser' om krigen i Irak: at man har fundet masseødelæggelsesvåben, at Irak og Al-Qaeda har samarbejdet, og at verdensopinionen støttede krigen. De amerikanere, der fulgte Fox News' dækning af krigen, var de mest forvirrede. ${ }^{11}$

Den republikanske selvretfærdige patriotisme forbliver imidlertid ikke uimodsagt. Græsrodsbevægelser som MoveOn.org gør brug af internettet for at mobilisere borgere til at vise modstand mod Bushs håndtering af krigen. ${ }^{12} \mathrm{Al}$-Qaeda og de irakiske oprøreres asymmetriske terror indeholder også et medieelement. Både de storstilede terroristangreb og guerillakrigen mod koalitionsstyrker og hjælpeorganisationer i Irak er udtænkt til at påvirke offentlig opinion i USA. Mens amerikanske politiske ledere prøver at fortrænge erfaringerne fra Vietnam, har modparten taget ved lære af dem. I dag, mere end 100 år efter starten på det første amerikanske århundrede i 1898 og på trods af teknologisk fremskridt i medieverden, er 
spørgsmålet, om den amerikanske offentlighed er bedre underrettet om regeringens reelle hensigter

\section{Litteratur}

Anderson, K. (2001, 26. september). The Pentagon and the Press. BBC News. Hentet fra http://news.bbc.co.uk/1/ hi/world/americas/1563909.stm.

Bennett, W. (2002). Why We Fight: Moral Clarity and the War on Terrorism. Washington: Regnery.

Beveridge, A. (1898, 16. september). The March of the Flag. Hentet fra 0 http://www.fordham.edu/halsall/ mod/1898beveridge.html).

Boot, M. (2002). The Savage Wars of Peace: Small Wars and the Rise of American Power. New York: Basic Books.

Campbell, WJ. (2000). Not likely sent: The Remington-Hearst 'telegrams'. Journalism and Mass Communication Quarterly, summer. Hentet fra http:// academic2.american.edu/ wjc/wjc3/notlikely.html.

Cronkite, W. (1998). We Are Mired in a Stalemate ... In Reporting Vietnam: Part One: American Journalism 1959-1969. New York: The Library of America, s. 581.

Dos Passos, J. (1930). USA. New York: Modern Library.

Dreyfuss, R. (2003). Just the Beginning. The American Prospect, vol. 14 no. 4 ,

Fussell, P. (1990). Wartime: Understanding and Behavior in the Second World War. Oxford: Oxford University Press.

Harris, P. \& Franklin, J. (2003, 10. august). 'Bring Us Home': G.I.s Flood US with War-Weary Emails. The Observer.

Hedges, C. (2003, 21. april). The Press and the Myths of War. The Nation.

Hedges, C. (2003). War is a Force that Gives Us Meaning. New York: Anchor.

Hersh, S. (2004, 10. maj). Torture at Abu Ghraib. The New Yorker.

Hollywood Considers Role in War Effort. (2001, 11. november). Hentet fra http://edition.cnn.com/2001/ US/11/11/rec.hollywood.terror/.

Lewis, D.L. (1993). W.E.B. Du Bois: Biography of a Race. New York: Henry Holt.

Mailer, N. (2003). Why Are We at War? New York: Random House, s. 10-15.

Mugridge, I. (1995). The View from Xanadu: William Randolph Hearst and United States Foreign Policy. Montreal \& Kingston: McGill-Queen's University Press.

Nash, G. et al. (1994). The American People. New York: Longman.

Nichols, J. (2003, 19. december). Fawning Over Bush. The Nation.

Ninkovich, F. (2001). The United States and Imperialism. Oxford: Blackwell, s. 15-22. og nærmere nogen sandhed om amerikansk krigsførelse i det 21. århundrede?

Sloyan, P.J. (2002, 25. november). Bodies? What Bodies? Hentet fra AlterNet: http://www.alternet.org/story. html? StoryID $=14633$.

Suid, L. (2002). Guts \& Glory: The Making of the American Military Image in Film. Lexington, KY: University Press of Kentucky.

Traxel, D. (1998). 1898: The Birth of the American Century. New York: Vintage, s. 186-203.

\section{Noter}

1 Eksplosionen skete formentlig pga. en brand opstået i maskinerummet (Ninkovich, 2001, s. 25).

2 Man kan læse et udsnit af Cranes reportage fra Cuba i Stephen Crane. (1984). New York: The Library of America.

3 Nogle af Reeds artikler fra krigen findes i O'Neill, W.L. (ed.). (1966). Echoes of Revolt: The Masses 1911-1917. Chicago: Ivan R. Dee.

4 Suid, 2002, s. 16-23. Forholdet mellem militær og filmindustri er et gennemgående tema i Suids bog. I et appendiks har Suid en liste over, hvorvidt de film, han omtaler, fik støtte fra militæret.

5 Se samlingen Reporting World War II vols. 1 E 2. (1995). Washington: Library of America.

6 Robert McNamara, der var forsvarsminister under Kennedy og Johnson, har erkendt den fejlslagne politik i Vietnam i bøger og i dokumentarfilmen The Fog of War (2003).

7 Christiane Amanpour, "The Gulf War Pool System" fra PBS-serien Reporting America at War hentet fra http:/ / www.pbs.org/weta/reportingamericaatwar/reporters/ amanpour/poolsystem.html

8 Hollywood Considers Role in War Effort. (2001, 11. november). Hentet fra http://edition.cnn.com/2001/ US/11/11/rec.hollywood.terror/

9 Om højredrejningen af nyhedsmedierne se Alterman, E. (2003). What Liberal Media?: The Truth About Bias and the Neres. New York: Basic Books.

10 Se Rikke Schubarts artikel i dette nummer af MedieKultur.

11 Misperceptions, The Media and The Iraq War: Program on International Policy Attitudes (2003, oktober). Hentet fra www.pipa.org/.

12 Se websiden www.moveon.org.

Carl Pedersen er lektor ved Københavns Universitet, Institut for Engelsk, Germansk og Romansk 